\title{
Evaluation of dividend policy of some selected public and private sector banks in India
}

\author{
Bhaskar Biswas $^{\mathbf{a}^{*}}$
}

${ }^{\mathrm{a}}$ Assistant professor of Commerce in Raja Rammohun Roy Mahavidyalaya, Radhanagar, Hooghly, India

\begin{tabular}{l}
\hline C H R O N I C L E \\
\hline Article history: \\
Received January 9, 2017 \\
Received in revised format \\
January 112017 \\
Accepted March 282017 \\
Available online \\
March 28 2017 \\
\hline Keywords: \\
Capital market \\
Dividend \\
Finance \\
Investment proposals \\
\hline
\end{tabular}
A B S T R A C T

Dividend is the part of profits of a company, which is distributable among its shareholders according to the decision taken and resolution passed in the meeting of Board of Directors. Dividend policy plays an important role for maintaining good image of company in the capital market and in providing source of low cost finance for financing for the profitable future investment proposals. In the present study, an attempt has been made to evaluate the dividend policy adopted by some selected public and private sector banks in India during the period of study March 2006 to March 2015.

\section{Introduction}

Dividend is considered as the portion of profits of a company, which is distributable among its shareholders according to the decision taken and resolution passed in the meeting of Board of Directors. Dividend may be paid as a fixed percentage on the share capital contributed by them or at a fixed amount per share. There is always a problem before the top management to decide how much profits should be transferred to reserve funds to meet any future contingencies and how much should be distributed to the equity shareholders as dividend. The corporation has to follow a sound dividend policy to solve the problem. According to Weston and Brigham (1972), "Dividend policy determines the division of earnings between payments to shareholders and retained earnings." According to Gitman and Zutter (2012), "The firm's dividend policy represents a plan of action to be followed whenever the dividend decision must be made." Dividend policy plays an important role for maintaining good image of company in the capital market and in providing source of low cost finance for financing for the profitable future investment proposals.

Pandey (2001) looks at the corporate dividend payout behavior of companies listed on the Kuala Lumpur stock exchange over the period 1993-2000. He categorizes the sample into six industries for examining the variation in the payout ratio. He also establishes a relationship between current earnings and past dividend rate. He finds that the Malaysian companies (by following Lintner's model) exhibit * Corresponding author. Tel: +91 9903689216 
unstable dividend behavior with high adjustments in dividend payments in order to meet the target payout ratio. Others find strong support for earnings, profit margin, institutional ownership and debtequity ratio on the dividend decision. Eriotis (2005) finds that Greek firms have a long-run constant dividend payout policy. He adjusts the firms' distributed earnings and size in the Lintner model and reports that an increase in the earnings does not change the dividend distribution pattern of firms.

Kania and Bacon (2005) find that variables such as sales growth, expansion and insider ownership have a negative impact on dividend decision but institutional ownership has an inverse relation with dividend payout, which is contrary to the existing literature. Denis and Osobov (2008) find that the tendency for paying dividends declined for countries such as United States, Canada, United Kingdom, Germany, France and Japan over the period 1994-2002. They also report that the international evidence does not support the investors' preference for dividend, the signaling and the clientele interpretations as prominent variables. Rather, they go along with the distribution of free cash flow as the chief element of the dividend decision.

Kevin (1992) analyzes the dividend payment behavior of 650 Indian companies during September 1983 to August 1984 and finds that profitability and earnings of the firms are the two foremost factors determining dividends. He concludes that Indian firms strive for achieving a stable dividend rate. However, keeping in view that the time of his study was only one year; his results cannot be taken as conclusive. Mahapatra and Sahu (1993) find that cash flows, current earnings and past dividends are prominent factors that have an impact on the dividend decision. Their results are in contrast to Lintner's model. Bhat and Pandey (1994) find that current year's earnings, pattern of past dividends, expected future earnings, changes in equity base of the firm have an impact on the dividend decision. Narasimhan and Asha (1997) look at the changes in dividend tax regime proposed in the Indian Union Budget of 1997-98 and analyze the impact of dividend tax on a firm's dividend decision. They conclude that the burden of tax payment fell in the hands of companies rather than their shareholders. Mohanty (1999) study more than 200 Indian companies for a period of fifteen years to understand the relationship between bonus-issuing and dividend-paying behavior of companies. He reports dividend rate is an important determinant of dividend policy in comparison to the dividend payout ratio.

Reddy Yarram (2002) analyzes the trends and determinants of dividend of all Indian companies listed on two major Indian stock exchanges-The Bombay Stock Exchange (BSE) and The National Stock Exchange (NSE) during 1990-2001. He investigates three factors viz., number of firms paying dividend, average dividend per share and the average payout. His results indicate that only few companies maintain the dividend payout rate and that firms forming a part of small indices pay higher dividend compared to firms forming a part of broad market indices. Deviations in the tax regime are also examined using the trade-off theory and it is found that this theory does not apply to the Indian corporate sector. He concludes that the omission of dividends have information content i.e. such companies expect lower earnings in the future whereas the same does not hold true in case of dividend initiations. Bhayani (2008) examines the influence of earnings and lagged dividend on dividend policy of companies listed on the BSE. He found that the current year's earnings is the foremost factor affecting the dividend behavior of a firm.

\section{Objectives of the study}

In the present study, an attempt has been made to evaluate the dividend policy adopted by some selected public and private sector banks in India during the period of study March 2006 to March 2015. More specifically the following are the objectives of the study:

1. To calculate three vital measures representing the dividend policy of some selected five public (Syndicate Bank, Uco Bank, Vijaya Bank, Canara Bank and Bank of India) and five private sector banks ( Karnataka Bank, Federal Bank, South Indian Bank, Karur Vysya Bank and Lakshmi Vilas Bank) in India during the period of study March 2006 to March 2015 
such as dividend per share (DPS), earning per share(EPS) and Dividend payout ratio(D/P Ratio),

2. To calculate two important parameters influencing dividend policy namely return on net worth (RONW), current ratio (CR),

3 To examine the impact of the profitability and liquidity of the business of the five public (Syndicate Bank, Uco Bank, Vijaya Bank, Canara Bank and Bank of India) and five private sector banks ( Karnataka Bank, Federal Bank, South Indian Bank, Karur Vysya Bank and Lakshmi Vilas Bank) on their dividend policy by computing co-efficient between DPS and each of the two important parameters influencing dividend policy.

\subsection{Research Methodology}

1. Selection of Data: Five public sector banks (Syndicate Bank, Uco Bank, Vijaya Bank, Canara Bank and Bank of India) and five private sector banks (Karnataka Bank, Federal Bank, South Indian Bank, Karur Vysya Bank and Lakshmi Vilas Bank) have been chosen for the study on the basis of the ratio of dividend yield to the current market prices of the shares of the banks as on the date 29.08.2015.

2. Collection of Data: This study is based on secondary data only. The secondary data have been collected from www.moneycontrol.com. Editing, classification and tabulation of the data collected from the above mentioned sources have been done as per the requirements of the study.

3. Analysis of Data: For analyzing the data simple mathematical tool like ratios, percentages etc. and statistical techniques like measures of central tendency, measures of dispersion, Karl Pearson's simple correlation and multiple correlation and regression analysis have been used.

\subsection{Limitations of the study}

1. The study is limited for a period 10 years from March 2006 to March 2015.

2. The study has taken into consideration five public sector banks (Syndicate Bank, Uco Bank, Vijaya Bank, Canara Bank and Bank of India) and five private sector banks (Karnataka Bank, Federal Bank, South Indian Bank, Karur Vysya Bank and Lakshmi Vilas Bank).

3. The study has used limited numbers of mathematical and statistical parameters.

\section{Analysis and interpretations}

Table 1 demonstrates the dividend per share (DPS) and earning per share(EPS) of some selected Public Sector Banks in India from year March 2006 to March 2015.

The results of Table 1 show the dividend per share (DPS) and earning per share(EPS) of some selected Public Sector Banks in India from year March 2006 to March 2015. From year 2005-06 to 2014-15 the DPS and EPS were highest for Canara Bank. The average DPS(9.61) and EPS(56.54) were highest for also for Canara Bank. Average DPS(1.71) was lowest for Uco Bank and average EPS(7.04) was lowest for Vijaya Bank. Standard deviation of DPS and EPS were highest for Canara Bank. Standard deviation of DPS and EPS were lowest for Vijaya Bank Co-efficient of variation of DPS and EPS were highest for Uco Bank and lowest for Canara Bank. 
Table 1

The information of dividend per share (DPS) and earning per share(EPS) of some selected Public Sector Banks in India from year March 2006 to March 2015

\begin{tabular}{lcccccccccc}
\hline & \multicolumn{4}{c}{ Dividend per share } & \multicolumn{6}{c}{ Earning per share } \\
\cline { 2 - 11 } Year & $\begin{array}{c}\text { *Synd } \\
\text { Bank }\end{array}$ & $\begin{array}{c}\text { Uco } \\
\text { Bank }\end{array}$ & $\begin{array}{c}\text { Vijaya } \\
\text { Bank }\end{array}$ & $\begin{array}{c}\text { Can } \\
\text { Bank }\end{array}$ & BOI & Synd & Uco & Vijaya & Can & BOI \\
& 2.50 & 0.00 & 1.00 & 6.60 & 3.00 & 10.28 & 2.46 & 2.93 & 32.76 & 14.39 \\
\hline 2006 & 2.80 & 1.00 & 2.00 & 7.00 & 3.50 & 13.72 & 3.95 & 6.67 & 34.65 & 23.04 \\
2007 & 2.80 & 1.00 & 2.00 & 8.00 & 4.00 & 16.25 & 5.16 & 8.21 & 38.17 & 38.26 \\
2008 & 3.00 & 1.00 & 1.00 & 8.00 & 8.00 & 17.49 & 10.15 & 4.79 & 50.55 & 57.26 \\
2009 & 3.00 & 1.50 & 2.50 & 10.00 & 7.00 & 15.58 & 18.42 & 10.34 & 73.69 & 33.15 \\
2010 & 3.70 & 3.00 & 2.50 & 11.00 & 7.00 & 18.28 & 14.45 & 9.08 & 90.88 & 45.54 \\
2011 & 3.80 & 3.00 & 2.50 & 11.00 & 7.00 & 21.82 & 16.68 & 9.05 & 74.10 & 46.66 \\
2012 & 6.70 & 1.60 & 2.50 & 13.00 & 10.00 & 33.30 & 8.21 & 9.41 & 64.83 & 46.14 \\
2013 & 5.50 & 3.00 & 2.00 & 11.00 & 5.00 & 27.40 & 14.89 & 4.84 & 52.86 & 42.45 \\
2014 & 3.70 & 2.00 & 1.50 & 10.50 & 5.00 & 23.00 & 10.58 & 5.11 & 52.87 & 25.67 \\
2015 & 1.85 & 1.71 & 1.95 & 9.61 & 5.95 & 19.71 & 10.50 & 7.04 & 56.54 & 37.26 \\
\hline Avg. & 1.37 & 1.03 & 0.60 & 2.09 & 2.22 & 6.83 & 5.55 & 2.51 & 19.13 & 13.08 \\
Standard & & & & & & & & & & \\
Deviation & & & & & & & & & & \\
C.V & 35.58 & 60.23 & 30.77 & 21.75 & 37.31 & 34.65 & 52.86 & 35.65 & 33.83 & 35.10 \\
\hline
\end{tabular}

Source: calculated data. * (Synd Bank= Syndicate bank, Can Bank= Canara Bank, BOI= Bank of India.)

Table 2

Dividend payout ratio $\{(\mathrm{dps} \times 100) / \mathrm{eps}\}$ of some selected Public Sector Banks in India

\begin{tabular}{lccccc}
\hline & \multicolumn{5}{c}{ Dividend payout ratio $\{($ dps x100)/eps } \\
\cline { 2 - 6 } & $\begin{array}{c}\text { Syndicate } \\
\text { Bank }\end{array}$ & $\begin{array}{c}\text { Uco } \\
\text { Bank }\end{array}$ & $\begin{array}{c}\text { Vijaya } \\
\text { Bank }\end{array}$ & $\begin{array}{c}\text { Canara } \\
\text { Bank }\end{array}$ & Bank of India \\
\hline 2006 & 24.31 & 0.00 & 34.13 & 20.15 & 20.85 \\
2007 & 20.41 & 25.32 & 29.99 & 20.20 & 15.19 \\
2008 & 17.23 & 19.38 & 24.36 & 20.96 & 10.45 \\
2009 & 17.15 & 9.85 & 20.88 & 15.83 & 13.97 \\
2010 & 19.26 & 8.14 & 24.18 & 13.57 & 21.12 \\
2011 & 20.24 & 20.76 & 27.53 & 12.10 & 15.37 \\
2012 & 17.41 & 17.99 & 27.62 & 14.84 & 15.00 \\
2013 & 20.10 & 19.49 & 26.57 & 20.05 & 21.67 \\
2014 & 20.07 & 20.15 & 41.32 & 20.81 & 11.78 \\
2015 & 20.43 & 18.90 & 29.35 & 19.86 & 19.48 \\
\hline Avg. & 19.66 & 16.00 & 28.59 & 17.84 & 16.49 \\
Standard & 2.13 & 7.59 & 5.76 & 3.38 & 4.03 \\
Deviation & & & & & \\
C.V & 10.83 & 47.44 & 20.15 & 18.95 & 24.44 \\
\hline
\end{tabular}

Source: calculated data

Table 2 shows the dividend payout ratio $\{(\operatorname{dps} \mathrm{x} 100) / \mathrm{eps}\}$ of some selected Public Sector Banks in India from year March 2006 to March 2015. From year 2005-06 to 2014-15 the dividend payout ratios were highest for Vijaya Bank. The average dividend payout ratio was highest for also for Vijaya Bank. Average dividend payout ratio was lowest for Uco Bank. Standard deviation of dividend payout ratio was highest for Uco Bank. Standard deviation of dividend payout ratio was lowest for Syndicate Bank. Co-efficient of variation of dividend payout ratio were highest for Uco Bank and lowest for Syndicate Bank. 
Table 3

Dividend per share(DPS) and earning per share(EPS) of the selected Private Sector Banks in India

\begin{tabular}{|c|c|c|c|c|c|c|c|c|c|c|}
\hline & \multicolumn{4}{|c|}{ Dividend per share } & \multicolumn{6}{|c|}{ Earning per share } \\
\hline & *KTK & Fed & S.I & Karur & Lakshmi & KTK & Fed & S.I & Karur & Lakshmi \\
\hline & Bank & Bank & Bank & Bank & Bank & Bank & Bank & Bank & Bank & Bank \\
\hline 2006 & 3.00 & 3.50 & 1.80 & 12.00 & 2.50 & 14.52 & 26.31 & 7.23 & 75.28 & 11.50 \\
\hline 2007 & 3.50 & 4.00 & 2.50 & 10.00 & 0.70 & 14.59 & 34.20 & 14.79 & 29.63 & 3.60 \\
\hline 2008 & 5.00 & 4.00 & 3.00 & 12.00 & 1.50 & 19.92 & 21.52 & 16.77 & 38.62 & 5.18 \\
\hline 2009 & 6.00 & 5.00 & 3.00 & 12.00 & 2.50 & 21.94 & 29.26 & 17.23 & 43.71 & 10.31 \\
\hline 2010 & 4.00 & 5.00 & 4.00 & 12.00 & 0.60 & 12.47 & 27.16 & 20.69 & 61.73 & 3.15 \\
\hline 2011 & 3.00 & 8.50 & 0.50 & 12.00 & 2.50 & 10.87 & 34.32 & 2.59 & 54.53 & 10.37 \\
\hline 2012 & 3.50 & 9.00 & 0.60 & 14.00 & 3.50 & 13.07 & 45.41 & 3.54 & 46.81 & 10.97 \\
\hline 2013 & 4.00 & 9.00 & 0.70 & 14.00 & 3.00 & 18.48 & 49.00 & 3.75 & 51.35 & 9.39 \\
\hline 2014 & 4.00 & 2.00 & 0.80 & 13.00 & 1.00 & 16.51 & 9.81 & 3.78 & 40.08 & 6.11 \\
\hline 2015 & 5.00 & 2.20 & 0.60 & 13.00 & 2.00 & 23.96 & 11.74 & 2.28 & 38.17 & 7.38 \\
\hline Avg. & 4.10 & 5.22 & 1.75 & 12.40 & 1.98 & 16.63 & 28.87 & 9.27 & 47.99 & 7.80 \\
\hline $\begin{array}{l}\text { Standard } \\
\text { Deviation }\end{array}$ & 0.97 & 2.68 & 1.29 & 1.17 & 0.99 & 4.32 & 12.72 & 7.24 & 13.29 & 3.13 \\
\hline C.V & 23.66 & 51.34 & 73.71 & 9.43 & 50.00 & 25.98 & 44.05 & 78.10 & 27.69 & 40.12 \\
\hline
\end{tabular}

Table 3 shows DPS and EPS of some selected Private Sector Banks in India from year March 2006 to March 2015. From year 2005-06 to 2014-15 the DPS and EPS were highest for Karur Vysya Bank. The average DPS(12.40) and EPS(47.99) were highest for also for Karur Vysya Bank. Average DPS(1.75) was lowest for South Indian Bank and average EPS(7.80) was lowest for Lakshmivilas Bank. Standard deviation of DPS was highest for Federal Bank and EPS were highest for Karur Vysya Bank. Standard deviation of DPS was lowest for Karnataka Bank and EPS were lowest for Lakshmivilas Bank. Coefficient of variation of DPS and EPS were highest for South Indian Bank and co-efficient of variation of DPS lowest for Karur Bank and co-efficient of variation of EPS lowest for Karnataka Bank.

Table 4

Dividend payout ratio $\{(\mathrm{dps} \times 100) / \mathrm{eps}\}$ of some selected Private Sector Banks in India

\begin{tabular}{lccccc}
\hline & \multicolumn{5}{c}{ Dividend payout ratio $\{($ dps x 100)/eps } \\
& $\begin{array}{c}\text { Karnataka } \\
\text { Bank }\end{array}$ & $\begin{array}{c}\text { Federal } \\
\text { Bank }\end{array}$ & $\begin{array}{c}\text { South Indian } \\
\text { Bank }\end{array}$ & $\begin{array}{c}\text { Karur Vysya } \\
\text { Bank }\end{array}$ & $\begin{array}{c}\text { Lakshmivilas } \\
\text { Bank }\end{array}$ \\
\hline 2006 & 20.67 & 13.30 & 24.90 & 15.94 & 21.74 \\
2007 & 23.99 & 11.70 & 16.90 & 33.75 & 19.44 \\
2008 & 25.10 & 18.60 & 17.89 & 31.07 & 28.96 \\
2009 & 27.35 & 17.09 & 17.41 & 27.45 & 24.25 \\
2010 & 32.08 & 18.41 & 19.33 & 19.44 & 19.05 \\
2011 & 27.60 & 24.77 & 19.31 & 22.00 & 24.11 \\
2012 & 26.78 & 19.80 & 16.95 & 29.91 & 31.91 \\
2013 & 21.65 & 18.37 & 18.67 & 27.26 & 31.95 \\
2014 & 24.23 & 20.39 & 21.16 & 32.44 & 16.37 \\
2015 & 20.87 & 18.74 & 26.32 & 34.06 & 27.10 \\
\hline Avg. & 25.03 & 18.12 & 19.88 & 27.33 & 24.49 \\
Standard Deviation & 3.56 & 3.63 & 3.30 & 6.27 & 5.44 \\
C.V & 14.22 & 20.03 & 16.60 & 22.94 & 22.21 \\
\hline
\end{tabular}

Source: calculated data.

Table 4 shows the dividend payout ratio $\{(\mathrm{dps} \times 100) / \mathrm{eps}\}$ of some selected Private Sector Banks in India from year March 2006 to March 2015. The average dividend payout ratio was highest for also for Karur Vysya Bank. Average dividend payout ratio was lowest for Federal Bank. Standard deviation of dividend payout ratio was highest for Karur Bank. Standard deviation of dividend payout ratio was 
lowest for South Indian Bank. Co-efficient of variation of dividend payout ratio were highest for Karur Bank and lowest for Karnataka Bank.

\subsection{Comparison}

The average highest DPS of Karur Vysya Bank (12.40) is more than the average highest DPS of Canara Bank (9.61). The lowest average DPS (1.74) was for South Indian Bank is higher than the lowest average DPS (1.71) was for Uco Bank. Though average EPS of Canara Bank (56.54) is higher than average EPS of Karur Vysya Bank (47.99). The highest Standard deviation of DPS of Federal Bank (2.68) is also higher than highest Standard deviation of DPS of Bank of India (2.22). Highest standard deviation of EPS of Canara Bank(19.13) is also higher than highest Standard deviation of EPS of Karur Bank (13.29). Co-efficient of variation of DPS and EPS of South Indian Bank are more than the co-efficient of variation of DPS and EPS of Uco Bank. But the highest average D/P Ratio of Vijaya Bank is more than the highest average D/P Ratio of Karur Bank. Also the highest standard deviation of $\mathrm{D} / \mathrm{P}$ Ratio of Uco Bank is more than the highest standard deviation of D/P Ratio of Karur Bank. And the highest Co-efficient of variation of D/P Ratio of Uco Bank is more than the highest Co-efficient of variation of D/P Ratio of Karur Bank.

Dividend per share (DPS) and return on net worth (RONW) of Syndicate Bank are negatively correlated that increase in RONW will lead to the decrease in the DPS which is statistically significant at $10 \%$ level of significance. Dividend per share (DPS) and return on net worth(RONW) of Uco Bank are positively correlated that increase in RONW will lead to the increase in the DPS which is statistically significant at 5\% level of significance. Dividend per share(DPS) and current ratio(CR) of Vijaya Bank are positively correlated that increase in CR will lead to the increase in the DPS which is statistically significant at $5 \%$ level of significance.

Table 5

Pearson's simple correlation analysis of dividend per share and selected factors of dividend policy

\begin{tabular}{lcc}
\hline Public sector banks & $\begin{array}{c}\text { Correlation coefficient between DPS } \\
\text { and RONW }\end{array}$ & $\begin{array}{l}\text { Correlation coefficient between DPS } \\
\text { and CR }\end{array}$ \\
\hline Syndicate Bank & $-0.35\left(\mathrm{t}=3.35^{* * *}\right)$ & $-0.08(\mathrm{t}=1.04)$ \\
Uco Bank & $0.15\left(\mathrm{t}=3.13^{* *}\right)$ & $0.58(\mathrm{t}=0.00)$ \\
Vijaya Bank & $0.47(\mathrm{t}=1.10)$ & $0.33(\mathrm{t}=3.07 * *)$ \\
Canara Bank & $-0.49(\mathrm{t}=0.00)$ & $0.53(\mathrm{t}=1.48)$ \\
Bank of India & $-0.08(\mathrm{t}=0.00)$ & $0.23(\mathrm{t}=1.42)$ \\
\hline Figures in bracket show [t] values & & \\
$* * *$ Significant at $10 \%$ level & & \\
$* *$ Significant at $5 \%$ level & & \\
$*$ Significant at $1 \%$ level & \\
Table values of $\mathrm{t}$ with $(\mathrm{n}-2)$ i.e 8 degrees of freedom at $10 \%, 5 \%, 1 \%$ levels are $1.86,2.306$ and 3.355 respectively \\
Source: moneycontrol.com
\end{tabular}

Table 6

Pearson's simple correlation analysis of dividend per share and selected factors of dividend policy

\begin{tabular}{lcc}
\hline Private sector banks & $\begin{array}{c}\text { Correlation coefficient between DPS } \\
\text { and RONW }\end{array}$ & $\begin{array}{l}\text { Correlation coefficient between DPS } \\
\text { and CR }\end{array}$ \\
\hline Karnataka Bank & $0.47(\mathrm{t}=1.13)$ & $-0.07\left(\mathrm{t}=3.11^{* *}\right)$ \\
Federal Bank & $-0.18(\mathrm{t}=0.00)$ & $-0.13(\mathrm{t}=0.00)$ \\
South Indian Bank & $-0.12\left(\mathrm{t}=1.98^{*}\right)$ & $0.01(\mathrm{t}=0.00)$ \\
Karur Vysya Bank & $-0.09(\mathrm{t}=0.00)$ & $-0.18\left(\mathrm{t}=9.75^{* * *}\right)$ \\
Lakshmi vilas Bank & $0.91(\mathrm{t}=4.77 * * *)$ & $0.22(\mathrm{t}=0.00)$ \\
\hline Figures in bracket show [t] values & & \\
$* * *$ Significant at $10 \%$ level & & \\
$* *$ Significant at $5 \%$ level & & \\
$*$ Significant at $1 \%$ level & & \\
Table values of $\mathrm{t}$ with $(\mathrm{n}-2)$ i.e 8 degrees of freedom at $10 \%, 5 \%, 1 \%$ levels are $1.86,2.306$ and 3.355 respectively \\
Source: moneycontrol.com
\end{tabular}


Dividend per share (DPS) and current ratio (CR) of Karnataka Bank are negatively correlated that increase in CR will lead to the decrease in the DPS which is statistically significant at $5 \%$ level of significance. Dividend per share (DPS) and return on net worth (RONW) of South Indian Bank are negatively correlated that increase in RONW will lead to the decrease in the DPS which is statistically significant at $1 \%$ level of significance. Dividend per share (DPS) and current ratio (CR) of Karur Vysya Bank are negatively correlated that increase in CR will lead to the decrease in the DPS which is statistically significant at 10\% level of significance. Dividend per share (DPS) and return on net worth (RONW) of Lakshmi vilas Bank are positively correlated that increase in RONW will lead to the increase in the DPS which is statistically significant at $10 \%$ level of significance.

\section{Conclusion}

It may be concluded from the above analysis that though the average DPS of most of the private sector banks selected for the study are more than that of selected public sector banks, the average DPS of Karur Vysya Bank (12.40) was highest. However, the average D/P Ratio of Vijaya Bank was highest. The highest average D/P Ratio of Vijaya Bank is more than the highest average D/P Ratio of Karur Bank. Though, average EPS of Vijaya Bank (7.04) was lowest. Standard deviation of DPS and EPS were lowest for Vijaya Bank. Dividend per share (DPS) and current ratio(CR) of Vijaya Bank are positively correlated that increase in CR will lead to the increase in the DPS which is statistically significant at 5\% level of significance. Therefore, it can be said that performance of the selected public sector banks are better than private sector banks in case of dividend policy. Among the public sector, the performance of Vijaya Bank is the best.

\section{Acknowledgement}

The authors would like to thank the anonymous referees for constructive comments on earlier version of this paper.

\section{References}

Bhayani, S. J. (2008). Dividend policy behaviour in the Indian capital market: A study of BSE-30 Companies. DIAS Technology Review, 4(1), 30-39.

Bhat, R., \& Pandey, I. M. (1994). Dividend Decision: A Study of Managers' Perception. Decision, 21(1), 67.

Denis, D. J., \& Osobov, I. (2008). Why do firms pay dividends? International evidence on the determinants of dividend policy. Journal of Financial Eeconomics, 89(1), 62-82.

Eriotis, N. (2005). The effect of distribution earnings and size of the firm to its dividend policy. International Business \& Economics Journal, 4(1), 45-51.

Gitman, L. J., \& Zutter, C. J. (2012). Principles of managerial finance. Prentice Hall.

Kania, S.L., \& Bacon, F.W. (2005). What factors motivate the corporate dividend decision?. American Society of Business and Behavioral Sciences E-Journal, 1(1).

Kevin, S. (1992). Dividend Policy: An analysis of some determinants. Finance India, 6(2), 253-259.

Mahapatra, R. P., \& Sahu, P. K. (1993). A note on determinants of corporate dividend behaviour in India-An econometric analysis. Decision, 20(1), 1.

Mohanty, P. (1999). Dividend and bonus policies of Indian companies: An analysis. Vikalpa, 24(4), $35-42$.

Narasimhan, M. S., \& Asha, C. (1997). Implications of dividend tax on corporate financial policies. The ICFAI Journal of Applied Finance, 3(2), 11-28.

Pandey, I. M. (2001). Corporate dividend policy and behaviour: the Malaysian experience.

Reddy Yarram, S. (2002). Dividend policy of Indian corporate firms: An analysis of trends and determinants. Technical Report, 1-47.

Weston, J.F. \& Brigham, E.F. (1972). Managerial Finance. 4th ed., NY: Holt, Rinehart \& Winston. 


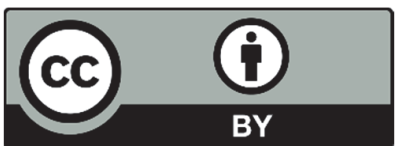

(C) 2017 by the authors; licensee Growing Science, Canada. This is an open access article distributed under the terms and conditions of the Creative Commons Attribution (CC-BY) license (http://creativecommons.org/licenses/by/4.0/). 